\title{
The Impact of Biosolid Application on Soil and Native Plants in a Degraded Brazilian Atlantic Rainforest Soil
}

\author{
Thalita Fernanda Sampaio - Iraê Amaral Guerrini • Xosé Luiz Otero • \\ Felipe Macías Vazquez • Julio Cesar Bogiani • Fernando Carvalho Oliveira • \\ José Luis Gava • Marcia A. Ciol • Kim M. Littke • Robert B. Harrison
}

Received: 1 April 2015 / Accepted: 12 November 2015 /Published online: 1 December 2015

(C) Springer International Publishing Switzerland (outside the USA) 2015

\begin{abstract}
We conducted a field experiment to determine whether application of biosolids (municipal sewage sludge) to degraded areas of the Brazilian Atlantic rainforest had the potential to contaminate native forest species with trace metals in the sandy soils of the region. Treatments consisted of $0,2.5,5,10,15$, and 20 dry $\mathrm{Mg}$ biosolids ha ${ }^{-1}$, with nine native pioneer, secondary, and climax tree species assessed for metal uptake: capixingui, aroeira-pimenteria, canafístula, cedro-rosa, mutamba, angico-vermelho, copaíba, jatobá, and jequitibá. Biosolid application did not have a statistically significant effect on metal concentrations in soil, and
\end{abstract}

T. F. Sampaio • I. A. Guerrini

Departamento de Solos e Recursos Ambientais, Universidade Estadual Paulista, Faculdade de Ciências Agronômicas, Caixa Postal 237, CEP 18603-970 Botucatu, SP, Brazil

T. F. Sampaio

e-mail: thalitafs2003@yahoo.com.br

I. A. Guerrini

e-mail: iguerrini@fca.unesp.br

\section{L. Otero · F. M. Vazquez}

Departamento de Edafología y Química Agrícola, Universidad de Santiago de Compostela, 15782 Santiago de Compostela, Spain

\section{L. Otero}

e-mail: xl.otero@usc.es

F. M. Vazquez

e-mail: felipe.macias.vazquez@usc.es
Cd was the only metal with increased availability. No increased metal uptake was seen in tree foliage sampled at 6 and 12 months after application. Additional longerterm study is recommended; however, the results of this study indicate biosolids could be used in Atlantic rainforest reclamation in degraded sandy soils with little impact on soil accumulation and tree uptake of trace metals.

Keywords Sewage sludge $\cdot$ Heavy trace metals $\cdot$ Typic Quartzipsamment · Residuals reuse

J. C. Bogiani

EMBRAPA Algodão, CP: 174. CEP: 58107-720 Campina

Grande, PB, Brazil

e-mail: julio.bogiani@embrapa.br

F. C. Oliveira

BIOSSOLO Agricultura e Ambiente. Rua Campos Sales, 1818.

CEP: 13416-310 Piracicaba, SP, Brazil

e-mail: fernando@biossolo.com.br

J. L. Gava

SUZANO Papel e Celulose. Rua Prudente Moraes, 3626. CEP:

08613-135 Suzano, SP, Brazil

e-mail: jgava@suzano.com.br

M. A. Ciol

University of Washington, Box 356490, Seattle, WA 98195, USA

K. M. Littke • R. B. Harrison $(\bowtie)$

School of Environmental and Forest Sciences, College of the Environment, University of Washington, Box 352100, Seattle, WA 98195, USA

e-mail: robh@uw.edu 


\section{Introduction}

Restoration of degraded Atlantic rainforest sites is often slowed by poor physical, chemical, and biological properties of soils resultant from previous intensive uses, such as grazing and agriculture (Bezerra et al. 2006). Application of organic amendments such as biosolids (i.e., treated municipal sewage sludge) can potentially restore soil properties associated with native forests more quickly than natural ecosystem processes of organic matter and nutrient accumulation over time. Biosolid application for native forest restoration could also potentially utilize organic waste that otherwise might require an alternate disposal method with negative environmental impacts and high cost. Avoiding the use of mineral fertilizers also conserves energy and natural resources (Henry et al. 1993; Henry et al. 1994; Harrison et al. 1994; Andreoli et al. 1999). Despite the potential benefits of the addition of organic matter and nutrients from biosolids to soil, contaminants, including trace metals, may cause problems related to plant toxicity and environmental contamination (Brallier et al. 1996; Dongsen et al. 1992; Yang et al. 1998; Bettiol and Camargo 2000).

Much of the degraded land in developing countries such as Brazil is located in tropical regions, and studies of the interaction of biosolids with tropical soils are few in number. Understanding the potential negative impact of biosolid application would ideally utilize long-term studies, since some negative mechanisms may require time to be realized and detectable (Tsutiya et al. 2002; Harrison et al. 1994; Harrison et al. 1996). Generally, movement of metals resulting from biosolid application is limited and primarily observed in studies where acidic sandy soils with low organic matter content were treated with high rates of biosolids (Hue 1995; Brallier et al. 1996). In these cases, movement of metals into the soil profile was relatively rapid in the first few years, and did not increase greatly with additional time periods up to 20 years.

Plant species tolerant to high rates of biosolid application generally accumulate trace metals in roots rather than in the aerial portion (Marques 2000). and in most cases where toxicity was noted, accumulation occurred relatively quickly after biosolid application. In Brazil, the few studies that have utilized biosolids as a soil amendment have shown promising results both in use for seedling production (Trigueiro and Guerrini 2003) and in soil improvement for reforestation (Gonçalves et al. 2000; Poggiani et al. 2000). In those studies, results were similar to the more abundant research performed in temperate regions; however, the potential for the migration of metals through the soil profile was not investigated. The purpose of this study was to investigate the potential for tree uptake and mobililization and movement of trace metals in the soil profile of a degraded Atlantic rainforest soil during the first year after application of municipal biosolids.

\section{Material and Methods}

\subsection{Site Description}

The experiment was conducted at the Entre-Rios Farm of the Suzano Bahia Sul Papel e Celulose Company, in the region of Itatinga, São Paulo, Brazil, at approximately $23.3^{\circ} \mathrm{S}, 48.5^{\circ} \mathrm{W}$, where the average elevation is $636 \mathrm{~m}$. The climate of this region is warm and temperate with average annual temperature of $19.1^{\circ} \mathrm{C}$ and average annual rainfall of $1324 \mathrm{~mm}$. The primary wet season ranges from October to March, with a drier season April to September. The variation in the precipitation between the driest and wettest months is $195 \mathrm{~mm}$. The variation in temperatures throughout the year is $6.4{ }^{\circ} \mathrm{C}$ with the mean monthly temperature ranging from $22.0^{\circ} \mathrm{C}$ in January to $15.6^{\circ} \mathrm{C}$ in July. The area is characterized by relatively level, degraded soils (highly-compacted without topsoil), due to previous use for agriculture and timber storage. The soil of the experimental area is classified as a typic Quartzipsamment, according to the Brazilian and American Systems of Soil Classification (EMBRAPA 2006).

\subsection{Experimental design}

The field experimental design utilized four replicated blocks with six plots each, and one biosolid application rate for each plot ( 0 "control," 2.5, 5, 10, 15, and 20 dry $\mathrm{Mg} \mathrm{ha}^{-1}$ ). Biosolids from the sewage treatment plant of the city of Jundiaí, São Paulo State, were utilized for this study. Jundiaí treats wastewater initially in completely mixed aerated lagoons, followed by further treatment in a settling pond. Table 1 shows the metal composition of the Jundiaí biosolids compared to regulatory levels (NRC 1996) in Brazil and the USA and a range of biosolids and soils from the USA. Note that the maximum permitted concentration (MPC) in Brazil for the 
Table 1 Composition of biosolids compared to Brazilian and US standards

\begin{tabular}{|c|c|c|c|c|c|c|}
\hline Metal & $\begin{array}{l}\text { Brazilian } \\
\text { MPC }^{\mathrm{a}}\end{array}$ & $\begin{array}{l}\text { US EPA exceptional } \\
\text { quality }^{\text {b }}\end{array}$ & $\begin{array}{l}\text { US EPA ceiling } \\
\text { limits }^{c}\end{array}$ & $\begin{array}{l}\text { Range in US } \\
\text { soils }^{\mathrm{d}}\end{array}$ & $\begin{array}{l}\text { Biosolid conc., this } \\
\text { study }\end{array}$ & $\begin{array}{l}\text { Biosolid application } \\
\left(20 \mathrm{Mg} \mathrm{ha}^{-1}\right)\end{array}$ \\
\hline & & & & $\mathrm{mg} \mathrm{kg}^{-1}$ & & $\mathrm{~kg} \mathrm{ha}^{-1}$ \\
\hline As & 41 & 41 & 75 & $<0.1-97$ & 0.1 & 0.002 \\
\hline $\mathrm{Cd}$ & 39 & 39 & 85 & ND-11 & 8.2 & 0.16 \\
\hline $\mathrm{Cr}$ & 1000 & 1200 & 3000 & $1-2000$ & 163 & 3.3 \\
\hline $\mathrm{Ni}$ & 420 & 420 & 420 & $5-700$ & 38 & 0.76 \\
\hline $\mathrm{Pb}$ & 300 & 300 & 840 & $<10-700$ & 196 & 3.9 \\
\hline
\end{tabular}

${ }^{a}$ Brazilian maximum permitted concentration (CONAMA, 2006)

${ }^{\mathrm{b}}$ US EPA 503 national standards (adapted from NRC 1996)

${ }^{\mathrm{c}}$ US national sewage sludge survey (adapted from NRC 1996)

${ }^{\mathrm{d}}$ Data for US soils (adapted from NRC 1996)

metals is the same as the level for class A ("exceptional quality") biosolids in the USA, which indicates a lower legal application rate of metals in Brazil than the national standards for the USA (US EPA 2000). The class A level was developed by the US EPA to identify biosolids that are unlikely to cause problems when applied to land for the metals under consideration. Unlike Brazil, US law provides for application of biosolids at the higher concentration levels noted with additional restrictions.

Each plot received a different level of biosolids, assigned randomly. Each plot was split into a $9 \times 9$ grid, for a total of 81 subplots (Fig. 1). The border row was planted with Cytharexyllum myrianthum (Pau-viola) forming a treated border buffer between plants. The buffer trees were not analyzed. Each of the 49 internal subplots was planted with one of nine species of native trees, spaced at $3.0 \times 2.0 \mathrm{~m}$ between plants for a total area of $486 \mathrm{~m}^{2}$ per plot. Six application levels (treatments) per block and four blocks yield a total study area of 1.17 ha. The number of plants per group in each plot included eight pioneer, six secondary, and three climax species.

Tree species were selected based on their ecological and silvicultural importance to the Atlantic forest region, as well as being relatively common in native riparian forests. The Brazilian Atlantic Rainforest is considered to be one of, if not the most, biodiverse forest in the world in terms of the variety of tree species, so these nine species certainly cannot represent the natural biodiversity of a typical native rainforest, but this is among the first studies using these native species coupled with biosolid amendment of degraded soil. The species used were from three groups: pioneer, secondary, or climax. Pioneer species included capixingui (Croton floribundus Spreng) and aroeira-pimenteria (Schinus terebinthifolius Raddi). The secondary tree species used were canafístula (Peltophorum dubium (Spreng.) Taub.), cedro-rosa (Cedrela fissilis Vell.), mutamba (Guazuma ulmifolia Lam), and angico-vermelho (Anadenanthera macrocarpa (Benth.) Brenan). Three climax tree species were also planted: copaíba (Copaifera langsdorffii Desf.), jatobá (Hymenaea courbaril L.), and jequitibá (Cariniana estrellensis (Raddi) Kuntze). All plots were planted using the same pattern (Fig. 1) where pioneer, secondary, and climax species were alternated, and each subplot had one tree planted in its center.

The experiment started in March 2005, by ground clearing to remove invasive Brachiaria (signalgrass) vegetation and plowing to a depth of $40-50 \mathrm{~cm}$ to ameliorate previous soil compaction. Biosolids were applied in June 2005, and immediately incorporated into the soil by tillage to $20-\mathrm{cm}$ total depth. Tree seedlings were planted in August 2005.

\subsection{Soil Analysis}

Composite soil samples of 24 individual samples within each plot were collected uniformly from $0-$ to $20-\mathrm{cm}$ (same as incorporation) depths 6 and 12 months after the biosolid application. Total arsenic (As), cadmium (Cd), chromium $(\mathrm{Cr})$, lead $(\mathrm{Pb})$, and nickel $(\mathrm{Ni})$ were analyzed with digestion according to EPA method 3051 (US EPA 1994). and atomic absorption spectrophotometry 


\begin{tabular}{|c|c|c|c|c|c|c|c|c|c|}
\hline & 1 & 2 & 3 & 4 & 5 & 6 & 7 & 8 & 9 \\
\hline 1 & Pau-viola & Pau-viola & Pau-viola & Pau-viola & Pau-viola & Pau-viola & Pau-viola & Pau-viola & Pau-viola \\
\hline 2 & Pau-viola & Capixingui & Canafístula & $\begin{array}{c}\text { Aroeira- } \\
\text { pimenteira }\end{array}$ & Cedro-rosa & Capixingui & Mutamba & $\begin{array}{c}\text { Aroeira- } \\
\text { pimenteira }\end{array}$ & Pau-viola \\
\hline 3 & Pau-viola & Cedro-rosa & $\begin{array}{c}\text { Jequitibá- } \\
\text { branco }\end{array}$ & Mutamba & Jatobá & $\begin{array}{c}\text { Angico- } \\
\text { vermelho }\end{array}$ & Copaíba & Cedro-rosa & Pau-viola \\
\hline 4 & Pau-viola & $\begin{array}{c}\text { Aroeira- } \\
\text { pimenteira }\end{array}$ & $\begin{array}{c}\text { Angico- } \\
\text { vermelho }\end{array}$ & Capixingui & Canafístula & $\begin{array}{c}\text { Aroeira- } \\
\text { pimenteira }\end{array}$ & $\begin{array}{c}\text { Canafístula } \\
\text { Capixingui }\end{array}$ & Pau-viola \\
\hline 5 & Pau-viola & Canafístula & Jatobá & Cedro-rosa & Copaíba & Mutamba & $\begin{array}{c}\text { Jequitibá - } \\
\text { branco }\end{array}$ & $\begin{array}{c}\text { Angico- } \\
\text { vermelho }\end{array}$ & Pau-viola \\
\hline 6 & Pau-viola & Capixingui & Mutamba & $\begin{array}{c}\text { Aroeira- } \\
\text { pimenteira }\end{array}$ & $\begin{array}{c}\text { Angico- } \\
\text { vermelho }\end{array}$ & Capixingui & $\begin{array}{c}\text { Cedro-rosa } \\
\text { pimenteira }\end{array}$ & Pau-viola \\
\hline 7 & Pau-viola & Canafístula & Copaíba & Cedro-rosa & $\begin{array}{c}\text { Jequitibá - } \\
\text { branco }\end{array}$ & Canafístula & Jatobá & Mutamba & Pau-viola \\
\hline 8 & Pau-viola & $\begin{array}{c}\text { Aroeira- } \\
\text { pimenteira }\end{array}$ & $\begin{array}{c}\text { Angico- } \\
\text { vermelho }\end{array}$ & Capixingui & Mutamba & $\begin{array}{c}\text { Aroeira- } \\
\text { pimenteira }\end{array}$ & $\begin{array}{c}\text { Angico- } \\
\text { vermelho }\end{array}$ & Capixingui \\
\hline 9 & Pau-viola & Pau-viola & Pau-viola & Pau-viola & Pau-viola & Pau-viola & Pau-viola & Pau-viola & Pau-viola \\
\hline
\end{tabular}

Fig. 1 Distribution of plant species in each of six plots within a block

(Perkin Elmer, Model 1100B, Perkin Elmer Corporation, 520 South Main St, Akron, OH 44311). To calculate the means for each treatment level at month 12, we used values of $249 \mu \mathrm{g} \mathrm{kg}^{-1}$ soil for nondetectable $\mathrm{Pb}$ $\left(<250 \mu \mathrm{g} \mathrm{kg}^{-1}\right.$ soil), calculated from the detection limits of the procedures and equipment utilized. Total As, Cd, $\mathrm{Cr}$, and $\mathrm{Ni}$ were above detection levels and were quantified. Soil extractable As and $\mathrm{Cd}$ concentrations were also determined by extraction of soil with a $1 \mathrm{~N} \mathrm{HCl}$ and atomic absorption spectroscopy (Tedesco et al. 1995).

\subsection{Foliage Analysis}

For each species, 6 and 12 months after planting, recently matured leaves were collected from the upper third of the tree crowns in the four cardinal directions, avoiding sampling both very young and senescent leaves. Foliage of all trees of the same species were mixed and analyzed together (giving one observation per species per plot). Foliage was dried at $65^{\circ} \mathrm{C}$ in forced air ovens and ground in a Wiley-type mill to $0.15 \mathrm{~mm}$. Chemical analysis of $\mathrm{As}, \mathrm{Cd}, \mathrm{Cr}, \mathrm{Pb}$, and $\mathrm{Ni}$ was performed by nitric-perchloric digestion according Malavolta et al. (1997). with determination of solution metals by atomic absorption spectrophotometry.

\subsection{Statistical Analysis}

Soil concentrations of heavy metals over time (6 and 12 months) and for treatment levels (0, 2.5, 5, 10, 15, and $20 \mathrm{Mg} \mathrm{ha}^{-1}$ biosolids) was analyzed using repeated measures analysis of variance (ANOVA; SPSS 2012). including an interaction of time by treatment. Similarly, foliar concentration of heavy metals over time, according to treatment level and species was analyzed through repeated measure ANOVA including all interactions between time, treatment, and species. We only used pioneer and secondary species in the foliar analysis since there was not enough material to be sent to the laboratory for analysis of climax species (too little foliage in young plants at 6 months due to slow growth and lack of foliage because of senescence during the dry season at 12 months).

\section{Results and Discussion}

The biosolids used in this study contained trace metal concentrations below the standards established by the Conselho Nacional do Meio Ambiente (CONAMA 2006) and the Companhia Ambiental do Estado de São Paulo (CETESB 1999). which regulates the use of 
biosolids in agriculture in the Brazilian state of São Paulo (Table 1). According to Marques et al. (2006). even though the levels of trace metals found in biosolids were below both the legal maximum permitted concentration and the US EPA class A quality guidelines, studies on the application of different doses of this residue to the soil are still critical because metals present in biosolids that are applied to soil will be added either to metal existing naturally in the environment (Andreoli et al. 2006) or to metal from other anthropogenic sources, including industrial emissions, effluents, fertilizers, soil conditioners, and pesticides (Silveira 2003). Based on the highest dose of biosolids applied to the soil $\left(20 \mathrm{Mg} \mathrm{ha}^{-1}\right)$ and a measured bulk density of $1000 \mathrm{~kg} \mathrm{~m}^{3}$, the added metal quantities were approximately $0.002,0.16,3.30,0.76$, and $3.90 \mathrm{~kg} \mathrm{ha}^{-1}$ of $\mathrm{As}, \mathrm{Cd}, \mathrm{Cr}, \mathrm{Ni}$, and $\mathrm{Pb}$, respectively (Table 1), with correspondingly lower loading rates at the lower application rates.

\subsection{Addition of Trace Metals to Soil}

Soils were analyzed 12 months after the biosolid application for trace metal concentrations (Table 2). In all cases, the high variability of metals in soil analysis did not show a uniform and statistically significant increase in metal concentration vs. rate of biosolids applied. Due to the relatively low metal concentrations of the biosolids (Table 1), low application rates and metal loading relative to background metal concentrations, and operational difficulty in thoroughly mixing biosolids with soil such small changes in biosolid-amended soils compared to the control soil are not completely unexpected (Hamel et al. 2003).

The treatment that best followed the predicted increase in soil As was the $10 \mathrm{Mg} \mathrm{ha}^{-1}$ application rate; all other treatments resulted in a lower observed change than expected except in the case of Cd (Table 2). The $10 \mathrm{Mg} \mathrm{ha}^{-1}$ application rate also showed the greatest increase in $\mathrm{Cr}$ and $\mathrm{Ni}$ over the other application rates. Arsenic was the only trace metal that showed a trend of increasing concentration with application rate.

The actual increase in $\mathrm{Cd}$ due to the biosolid treatment were much higher than what was predicted from the application rate (Table 2); observed increases in soil Cd were between 2 and 13 times higher than predicted, and the highest increases were seen in the lower application rate treatments. This could be due to nonuniform mixing of biosolids into the soil profile. However, the increase was not directly linear with the application rate

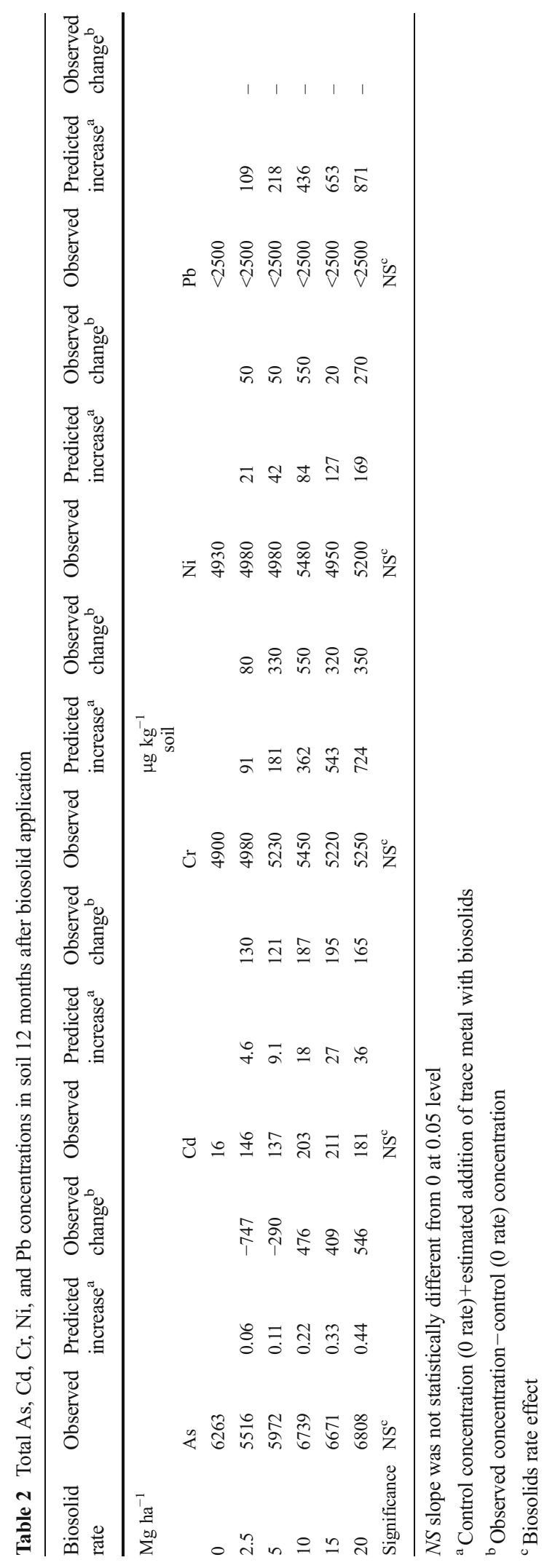


Table 3 Mean extractable As and Cd concentrations in soil 6 and 12 months after biosolid application

\begin{tabular}{|c|c|c|c|c|}
\hline \multirow{2}{*}{$\begin{array}{l}\text { Biosolid rate } \\
\text { Months }\end{array}$} & \multicolumn{2}{|c|}{ Extractable As } & \multicolumn{2}{|c|}{ Extractable $\mathrm{Cd}$} \\
\hline & 6 & 12 & 6 & 12 \\
\hline $\mathrm{Mg} \mathrm{ha}^{-1}$ & \multicolumn{4}{|c|}{$\mu \mathrm{g} \mathrm{kg}^{-1}$ soil } \\
\hline 0 & 60 & 110 & 10 & 10 \\
\hline 2.5 & 30 & 130 & 40 & 100 \\
\hline 5 & 50 & 80 & 90 & 70 \\
\hline 10 & 30 & 70 & 120 & 160 \\
\hline 15 & 140 & 90 & 200 & 160 \\
\hline 20 & 190 & 120 & 330 & 140 \\
\hline \multicolumn{5}{|l|}{ ANOVA, $p$ values for } \\
\hline Time & 0.65 & & 0.54 & \\
\hline Treatment & 0.34 & & 0.001 & \\
\hline Time $\times$ treatment & 0.64 & & 0.49 & \\
\hline
\end{tabular}

of biosolids, and it is not known with certainty why we observed these unexpected results.

The estimated amounts of $\mathrm{Pb}$ added would result in increases and total soil concentrations below the detection limit of $\mathrm{Pb}$ for the method used $\left(2500 \mu \mathrm{g} \mathrm{kg}^{-1}\right)$, so little could be inferred related to the impact of the application of biosolids on soil $\mathrm{Pb}$. It has been noted in other studies that EPA 3051 sometimes does not extract all of total soil $\mathrm{Pb}$ (Hamel et al. 2003).

\subsection{Extractable Soil Trace Metals}

Since much of the concentration of $\mathrm{As}, \mathrm{Cd}, \mathrm{Cr}, \mathrm{Ni}$, and $\mathrm{Pb}$ is expected to be bound to soil solids and relatively unavailable to plants (Brallier et al. 1996). soil samples were also analyzed at 6 and 12 months after biosolid application for extractable metals. Extractable As and $\mathrm{Cd}$ were the only metals that had concentrations above the detection limits of the procedures and equipment used (Table 3). Extractable $\mathrm{Cr}$, Ni, and $\mathrm{Pb}$ were below detection limits of 3000,3000 , and $25,000 \mu \mathrm{g} \mathrm{kg}^{-1}$, respectively, and are not shown. Extractable As and $\mathrm{Cd}$ increased in the $2.5-10 \mathrm{Mg} \mathrm{ha}^{-1}$ application rates from 6 to 12 months, while extractable metals decreased in the $15-20 \mathrm{Mg} \mathrm{ha}^{-1}$ application rates over the same time period. A repeated measures ANOVA showed that neither the time (6 vs. 12 months), nor the treatment level were statistically significant in the model, which might be due to the large variation among plots (Fig. 2). Though surface biosolid applications and tillage to $20 \mathrm{~cm}$ were made as uniformly as possible, it is not uncommon for high variation in subsequent soil sampling to be observed (Brallier et al. 1996).

Soil extractable $\mathrm{Cd}$ followed a very similar trend with biosolid application rate (Table 3). For instance, available $\mathrm{Cd}$ measured 6 months after biosolid application increased from 10 to $330 \mu \mathrm{g} \mathrm{kg}^{-1}$ from the 0 to the $20 \mathrm{Mg} \mathrm{ha}^{-1}$ rates, respectively. A repeated measures
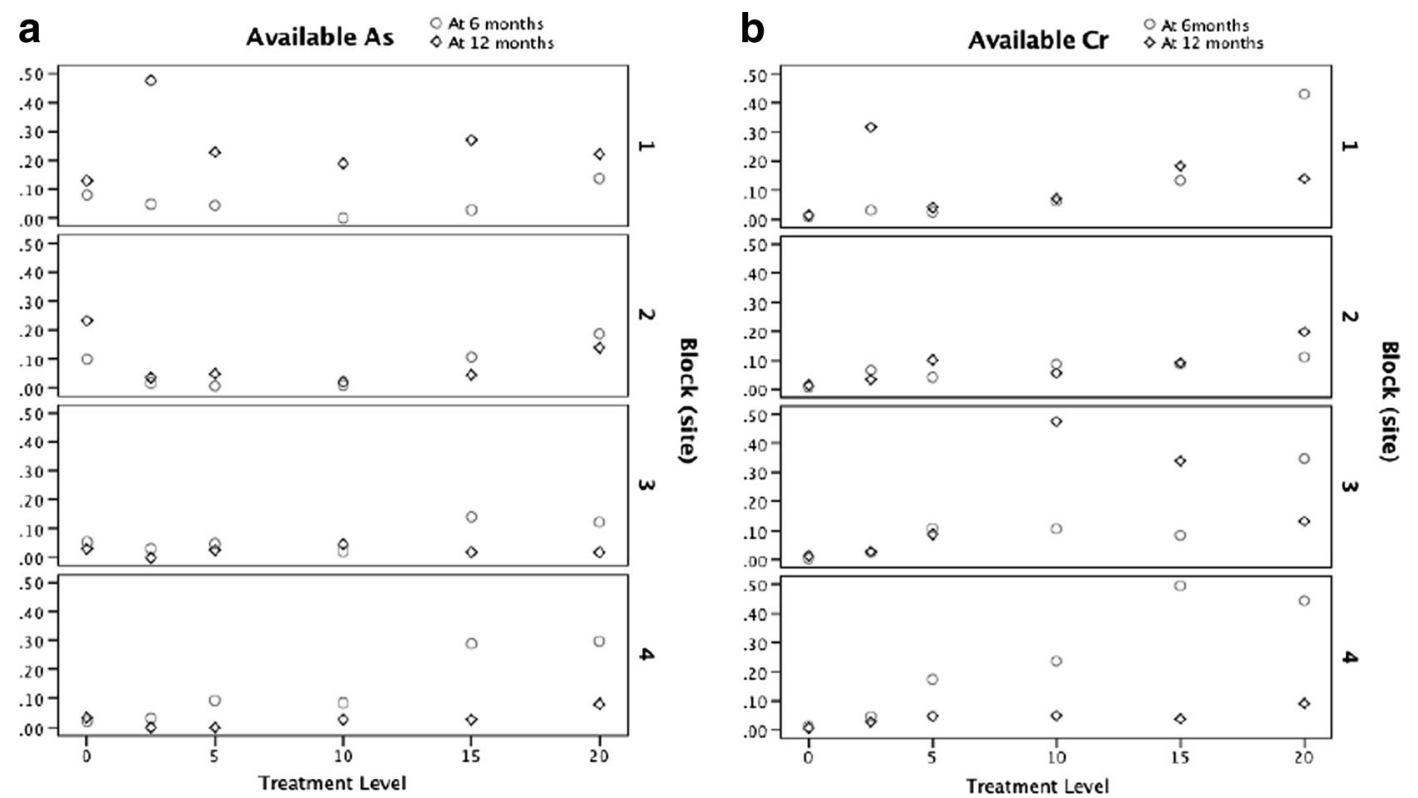

Fig. 2 Extractable As (a) and $\mathrm{Cr}$ (b) according to block (site) at 6 and 12 months 
Table 4 Foliar As, Cd, Cr, Ni, and $\mathrm{Pb}$ concentrations 6 and 12 months after biosolid application (including pioneer and secondary species and excluding climax tree species)

\begin{tabular}{|c|c|c|c|c|c|c|c|c|c|c|}
\hline \multirow{2}{*}{$\begin{array}{l}\text { Months } \\
\text { Biosolid rate }\end{array}$} & 6 & 12 & 6 & 12 & 6 & 12 & 6 & 12 & & 12 \\
\hline & \multicolumn{2}{|c|}{ Foliar As } & \multicolumn{2}{|c|}{ Foliar Cd } & \multicolumn{2}{|c|}{ Foliar Cr } & \multicolumn{2}{|c|}{ Foliar Ni } & \multicolumn{2}{|c|}{ Foliar $\mathrm{Pb}$} \\
\hline $\mathrm{Mg} \mathrm{ha}^{-1}$ & \multicolumn{10}{|c|}{$\mu \mathrm{g} \mathrm{kg}^{-1}$ foliage } \\
\hline 0 & 0.13 & 0.09 & 0.06 & 0.02 & 50 & 42 & 43 & 31 & 411 & 555 \\
\hline 2.5 & 0.24 & 0.08 & 0.06 & 0.02 & 133 & 53 & 55 & 29 & 904 & 108 \\
\hline 5 & 0.23 & 0.09 & 0.01 & 0.02 & 137 & 271 & 30 & 205 & 462 & 345 \\
\hline 10 & 0.26 & 0.15 & 0.01 & 0.02 & 59 & 53 & 63 & 11 & 1185 & 229 \\
\hline 15 & 0.22 & 0.08 & 0.02 & 0.01 & 49 & 38 & 56 & 21 & 909 & 705 \\
\hline 20 & 0.18 & 0.23 & 0.02 & 0.02 & 124 & 239 & 41 & 191 & 1100 & 494 \\
\hline \multicolumn{11}{|l|}{ ANOVA, $p$ values for } \\
\hline Time & 0.002 & & 0.18 & & 0.62 & & 0.41 & & 0.03 & \\
\hline Treatment & 0.16 & & 0.38 & & 0.35 & & 0.59 & & 0.67 & \\
\hline Species & 0.41 & & 0.57 & & 0.21 & & 0.21 & & 0.26 & \\
\hline Time $\times$ treatment & 0.30 & & 0.53 & & 0.76 & & 0.35 & & 0.34 & \\
\hline Time $\times$ species & 0.79 & & 0.48 & & 0.40 & & 0.36 & & 0.90 & \\
\hline Species $\times$ treatment & 0.84 & & 0.38 & & 0.67 & & 0.90 & & 0.79 & \\
\hline Time $\times$ species $\times$ treatment & 0.61 & & 0.41 & & 0.79 & & 0.75 & & 0.42 & \\
\hline
\end{tabular}

Mean concentrations are averaged over species

ANOVA showed a statistically significant effect of treatment $(p=0.001)$, but no significant effect of time or the interaction time by treatment. As with As, the potential for Cd leaching out of soil was not investigated, though research in similar soils has shown low potential for leaching (Mattos et al. 1996).

\subsection{Trace Metal Uptake in Foliage}

Foliar uptake of metals and the potential for metals entering the food chain of grazing animals was investigated by sampling foliage at 6 and 12 months following biosolid application. Climax species (Jequitibá-branco, jattobá, and copaiba) were excluded from this analysis due to excessive number of missing values due to slow growth and small amounts of foliage early, and senescence during the dry season.

No interactions between treatment, species, and time and foliar uptake were statistically significant (Table 4). Only time (6 and 12 months) was statistically significant for foliar $\mathrm{As}(p=0.001)$ and $\mathrm{Pb}(p=0.03)$. In general, the level of foliar concentration of heavy metals decreased over time. Some possibilities for the observed results of very low foliar metals is that plants accumulated the available metals in their root systems (Marques 2000). that metals were diluted with uptake by the high production of organic matter or there was low metal availability in the soil.

Oliveira and Mattiazzo (2001) found that trace metal uptake in foliage by sugar cane in an Oxisol treated with biosolids was very low or undetectable, though they did observe increases with higher biosolid application rates in soil. Similarly, Velasco-Molina et al. (2006) did not observe $\mathrm{Cd}$ and $\mathrm{Cr}$ foliar uptake at biosolid application rates as high as $40 \mathrm{Mg} \mathrm{ha}^{-1}$. These results are also consistent with other studies of metal uptake by Brallier et al. (1996). where soluble and extractable trace metal concentrations and trace metal uptake was very low, even though soil total metal concentrations were higher. These results suggest that there will be no effect of similar biosolid applications on foliar uptake by trees and therefore little influence on grazing animals.

\section{Conclusions}

In this study, trace metal contamination of soil and trees by biosolid applications appears to be negligible when applied up to $20 \mathrm{Mg} \mathrm{ha}^{-1}$ due to the low concentrations of metals, relatively low application rates, and the strong binding of metals in soil. The results of this study show that biosolids can likely be utilized in an 
environmentally safe manner with little chance of metals becoming highly bioavailable, at least under the conditions utilized in this study.

Acknowledgments The authors thank Fundação de Amparo à Pesquisa do Estado de São Paulo (FAPESP), Conselho Nacional de Pesquisa e Desenvolvimento (CNPq), Suzano Papel e Celulose; Estação de Tratamento de Esgoto de Jundiaí, and Faculdade de Ciências Agronômicas-FCA/UNESP for financial and structural support.

\section{References}

Andreoli, V. C., Fernandes, F., \& Lara, A. I. (1999). Reciclagem de biossólidos: transformando problemas em soluções. Curitiba, PR, Brazil: Sanepar.

Andreoli, C. V., Pegorini, E. S., Hoppen, C., Tamanini, C. R., \& Neves, P. S. (2006). Produção, composição e constituição de lodo de estação de tratamento de água. In C. V. Andreoli (Ed.), Alternativas de uso de resíduos do saneamento (pp. 29-48). Rio de Janeiro, RJ, Brazil: ABES.

Bettiol, W., \& Camargo, O. A. (2000). Impacto ambiental do uso agrícola de lodo de esgoto. Brasília, DF, Brazil: Embrapa.

Bezerra, F. B., Oliveira, M. A. C. L., Perez, D. V., Andrade, A. G., $\&$ Meneguelli, N. A. (2006). Sewage sludge in the revegetation of degraded area. Pesquisa Agropecuária Brasileira, 41, 469-476.

Brallier, S., Harrison, R. B., \& Henry, C. L. (1996). Liming effects on availability of $\mathrm{Cd}, \mathrm{Cu}, \mathrm{Ni}$ and $\mathrm{Zn}$ in a soil amended with sewage sludge 16 years previously. Water, Air, and Soil Pollution, 86, 195-206.

Cetesb - Companhia de Tecnologia de Saneamento Ambiental. (1999). Aplicação de lodos de sistemas de tratamento biológico em áreas agrícolas - Critérios para projeto $e$ operação. São Paulo, SP, Brazil: CETESB.

Conama - Conselho Nacional do Meio Ambiente. 2006. Resolução n 375, de 29 de agosto de 2006. Define critérios e procedimentos para o uso agrícola de lodos de esgoto gerados em estações de tratamento de esgoto sanitário e seus produtos derivados, e dá outras providências. Ministério do Desenvolvimento Urbano e Meio Ambiente.

Dongsen, X., Harrison, R. B., \& Henry, C. L. (1992). Research on the Distribution of Nutrients and Heavy Metals in forest soil amended with municipal sewage sludge after 15 years. Acta Univ. Agric. Boreali-occidentalis, 20, 20-27.

Embrapa. (2006). Sistema brasileiro de classificação de solos. Brasília, DF, Brazil: Embrapa.

Gonçalves, J. L. M., Santarelli, E. G., Moraes Neto, S. P., \& Manara, M. P. (2000). Produção de mudas de espécies nativas: substrato, nutrição, sombreamento e fertilização. In J. L. M. Gonçalves \& V. Benedetti (Eds.), Nutrição e fertilização florestal (pp. 80-102). Piracicaba, SP, Brazil: IPEF.

Hamel, S. C., Heckman, J. R., Shilke-Gartley, K. L., \& Hoskins, B. (2003). Lead extraction using three soil fertility tests and Environmental Protection Agency Method 3050.
Communications in Soil Science and Plant Analysis, 34, 2853-2873.

Harrison, R. B., Dongsen, X., Henry, C. L., \& Cole, D. W. (1994). Long-term effects of heavy applications of biosolids to coarse-textured soils: nutrients and general soil properties. Forest Ecology and Management, 66, 165-177.

Harrison, R. B., Gessel, S. P., Zabowski, D., Henry, C. L., Xue, D., Cole, D. W., \& Compton, J. E. (1996). Mechanisms of negative impacts of three forest treatments on nutrient availability. Soil Science Society of America Journal, 60, 16221628.

Henry, C. L., Cole, D. W., Hinckley, T. M., \& Harrison, R. B. (1993). The use of municipal and pulp and paper sludges to increase production in forestry. Journal of Sustainable Forestry, 1, 41-55.

Henry, C. L., Cole, D. W., \& Harrison, R. B. (1994). Use of municipal sludge to restore and improve site productivity in forestry: the Pack Forest Sludge Research Program. Forest Ecology and Management, 60, 137-149.

Hue, N. V. (1995). Sewage sludge. In J. E. Reichcigl (Ed.), Soil amendments environmental quality (pp. 199-247). Boca Raton, FL, USA: CRC Press.

Malavolta, E., Vitti, G. C., \& Oliveira, S. A. (1997). Avaliação do estado nutricional das plantas: princípios e aplicações. Piracicaba, SP, Brazil: Potafos.

Marques, T. C. L. L. S. M., Moreira, F. M. S., \& Siqueira, J. O. (2000). Growth and metal concentration of seedlings of woody species in a heavy metal contaminated soil. Pesquisa Agropecuária Brasileira, 35, 121-132.

Marques, M. O., Nogueira, T. A. R., Fonseca, I. M., \& Marques, T. A. (2006). Heavy metals concentration in soil amended with sewage sludge and sugarcane cropped. Colloquium Agrariae, 2, 46-56.

Mattos, A. T., Fontes, M. P. F., Jordão, C. P., \& Costa, L. M. (1996). Heavy metals mobility and retention forms in A Brazilian Oxisol. Revista Brasileira de Ciência do Solo, 20, 379-386.

NRC (National Research Council of the National Academies). (1996). Use of Reclaimed Water and Sludge in Food Crop Production. Washington, DC: The National Academies Press.

Oliveira, F. C., \& Mattiazzo, M. E. (2001). Heavy metals in an oxisol treated with sewage sludge and in sugarcane plants. Scientia Agricola, 58, 581-593.

Poggiani, F., Guedes, M. C., \& Bernadetti, V. (2000). Aplicação de biossólido em plantações florestais: I. Reflexo no ciclo dos nutrientes. In N. Bettiol \& O. A. Camargo (Eds.), Impacto ambiental do uso agrícola do lodo de esgoto (pp. 163-178). Brasília, DF, Brazil: Embrapa.

Silveira, M. L. A., Alleoni, L. R. F., \& Guilherme, L. R. G. (2003). Biosolids and heavy metals in soils. Scientia Agricola, 60, 793-806.

SPSS version 22 (IBM Corporation, 2012).

Tedesco, M. J., Gianello, C., Bissani, C. A., Bonhen, H., \& Volkweiss, S. J. (1995). Análise de solo, plantas e outros materiais (2nd ed., p. 147). Porto Alegre: Universidade Federal do Rio Grande do Sul, Departamento de Solos. Boletim Técnico, 5.

Trugueiro, R. M., \& Geriini, I. A. (2003). oUso de biossólido como substrato para produção de mudas de eucalipto. Scientia Forestalis, 63, 150-162. 
Tsutiya, M. T., Comparini, J. B., Sobrinho, P. A., Hespanhol, I., Carvalho, P. C. T., Melfi, A. J., Melo, W. J., \& Marques, M. O. (2002). Biossólidos na Agricultura. São Paulo, SP, Brazil: ABES.

US EPA. (1994). Method 3051. Microwave assisted acid digestion of sediments, sludges, soils and soils.

US EPA. (2000). Guide to the field storage of biosolids. Washington D.C: Office of Wastewater Management. EPA/ 832-B-00-007.
Velasco-Molina, M., Mattiazzo, M. E., Andrade, C. A., \& de Poggiani, F. (2006). Nitrogênio e metais pesados no solo e em árvores de eucalipto decorrentes da aplicação de biossólido em plantio florestal. Scientia Forestalis (IPEF), 71, 25-35.

Yang, L., Xue, D., Henry, C. L., \& Harrison, R. B. (1998). Biosolids application and the effect on heavy metals. AgroEnvironmental Protection, 16, 227-231. 